\title{
An Evaluation of Liver Function Tests in SARS-CoV-2 infection in the backdrop of chronic kidney disease.
}

Rajeev Kumar ${ }^{1}$, Pratip Jana ${ }^{1}$, Indu Priyadarshini ${ }^{2}$, Smita Roy ${ }^{1 *}$, Pritha Datta ${ }^{1}$, Saswati Das ${ }^{1}$

${ }^{1}$ Department of Biochemistry, ABVIMS \& Dr. RML Hospital, New Delhi 110001, India

${ }^{2}$ Department of Pharmacology ABVIMS \& Dr. RML Hospital, New Delhi 110001, India

*Corresponding author. Smita Roy, Assistant Professor, Department of Biochemistry, ABVIMS \& Dr. RML Hospital, New Delhi 110001, India. Email ID - drsroyresearch@gmail.com

\section{ABSTRACT \\ INTRODUCTION}

The SARS-CoV-2 pandemic has emerged as perhaps the most challenging global health problem of this century. The concomitant presence of co-morbidities like chronic kidney disease (CKD), diabetes, chronic heart disease etc. makes the task of patient management difficult.

\section{AIMS AND OBJECTIVES}

To assess the patterns of liver test abnormalities in patients of COVID-19 infection with and without CKD and evaluate the probable outcomes.

\section{MATERIALs and METHODS}

A cross-sectional retrospective observational study done on 600 patient samples (Group 1 COVID-19 without CKD, Group 2 COVID-19 with CKD and Group 3 non COVID-19 with CKD) which were processed for Liver function test (AST, ALT and ALP) and Renal function test (Urea and Creatinine) in the Department of Biochemistry, Dr. RML Hospital New Delhi.

\section{RESULTS}

AST and ALT levels were significantly higher $(\mathrm{P}<0.05)$ in all COVID-19 positive patients - group 1 mean $\pm 2 \mathrm{SD},(63.63 \pm 42.89 \mathrm{U} / \mathrm{L} \& 50.25 \pm 46.53 \mathrm{U} / \mathrm{L}$ respectively) and group $2(90.59 \pm 62.51$ $\mathrm{U} / \mathrm{L} \& 72.09 \pm 67.24 \mathrm{U} / \mathrm{L}$ respectively) as compared to Group $3(25.24 \pm 7.47 \mathrm{U} / \mathrm{L} \& 24.93 \pm$ $11.44 \mathrm{U} / \mathrm{L}$ respectively) and also a statistically significant elevation is seen in these two parameters (AST \& ALT) in Group 2 as compared to Group $1(P<0.05)$. There was a negative significant correlation between eGFR and AST/ALT levels in Group 1 ( $\mathrm{p}<0.05$ ). In Group 2, a weak positive correlation was seen with ALT ( $\mathrm{p}<0.01)$. 
medRxiv preprint doi: https://doi.org/10.1101/2021.07.16.21260406; this version posted July 22, 2021. The copyright holder for this preprint (which was not certified by peer review) is the author/funder, who has granted medRxiv a license to display the preprint in perpetuity. It is made available under a CC-BY-ND 4.0 International license.

No significant correlation existed between eGFR and ALP in groups 1 and 2. In Group 3, eGFR's showed strong correlations with AST and ALT levels $(\mathrm{p}<0.01)$ and reduction in kidney function correlated well with increase in serum ALP levels, $(\mathrm{p}<0.01)$.

\section{CONCLUSIONS}

This study most comprehensively describes that SARS-CoV-2 positive CKD patients show more elevations in serum aminotransferase levels as compared to their non-CKD counterparts, in contrast to non-COVID-19 CKD cases. Serum ALT values in SARS-CoV-2 patients show significant correlation with calculated eGFR values. Elevated ALP values in CKD patients may be used as an indicator of declining kidney function. However, more studies in this direction are needed.

Keywords

Amino-transferase, COVID-19, CKD, ALP, eGFR

\section{INTRODUCTION}

The SARS-CoV-2 pandemic commonly referred as COVID-19 disease has emerged as the most challenging global health problem of this century. Since its first emergence as a pneumonia of unknown cause, in Wuhan City, on the last day of 2019 and subsequent identification as the cause by Chinese authorities on $7^{\text {th }}$ January, $2020^{1}$ it has ravaged all continents and left a huge trail of death and devastation in its path. Initially christened as the novel coronavirus, the International Committee on Taxonomy of Viruses adopted the official name "severe acute respiratory syndrome coronavirus 2" (SARS-CoV-2) on 11 February $2020 .^{2}$ World Health Organization figures say, it has infected more than 100 million people and claimed more than 2.15 million lives worldwide. As on 07 June 2021, India reported 3.06 Cr confirmed cases and total of 4.03 L deaths have been reported. ${ }^{3}$

SARS-CoV-2 infection is primarily a disease of respiratory system. Although the pulmonary manifestations are the most common presentation, important extra-pulmonary events include gastrointestinal complications, cardiovascular injury, and renal dysfunction ${ }^{4-7}$.

The concomitant presence of co-morbidities like chronic kidney disease (CKD)-encompasses a huge gamut of conditions associated with a progressive decline in kidney functions and abnormal glomerular filtration rate, makes the task of patient management a daunting challenge for the attending physician. 
medRxiv preprint doi: https://doi.org/10.1101/2021.07.16.21260406; this version posted July 22, 2021. The copyright holder for this preprint (which was not certified by peer review) is the author/funder, who has granted medRxiv a license to display the preprint in perpetuity.

It is made available under a CC-BY-ND 4.0 International license .

The objective of this study is to compare the levels of the liver enzymes serum aspartate aminotransferase (AST), alanine aminotransferase (ALT) and serum alkaline phosphatase (ALP) levels among the three groups of subjects. Group 1 comprising of COVID-19 RT-PCR positive patients without CKD, Group 2 COVID-19 RT-PCR positive patients with CKD, and Group 3 COVID-19 RT-PCR negative CKD patients. In our paper we systematically assess the patterns of liver test abnormalities in patients of COVID-19 infection with and without $\mathrm{CKD}$, and further evaluate the probable outcome on the basis of these findings.

\section{Methodology}

This is a cross-sectional retrospective observational study conducted at the Department of Biochemistry, Atal Bihari Vajpayee Institute of Medical Sciences \& Dr. Ram Manohar Lohia Hospital, New Delhi, India. The data was collected from laboratory reports obtained using the hospital database, by biochemical analysis of blood samples, from patients admitted to the different COVID-19 designated wards/ICUs and Nephrology Unit of Atal Bihari Vajpayee Institute of Medical Sciences \& Dr. Ram Manohar Lohia Hospital, New Delhi, a tertiary care teaching center. Data from the month of July 2020 to November 2020 was analyzed.

A total of 600 patient samples were included in the study.454 RT-PCR positive SARS-Cov-2 subjects, of age $\geq 18$ years and of either sex, were included in the study. Among the study subjects 253 were cases of COVID-19 without altered renal function and 201 of COVID-19 with pre-existing renal disease (CKD stage 3 and 4). A second cohort of 219 non-COVID-19 cases (negative RT-PCR for SARS-Cov-2) with Stage 3 \& 4 CKD of similar demographic profile, were included in this study. The first 200 consecutive patient records in ascending order of their patient unique identification number in each group were included in the study. Cases with active COVID-19 infection from COVID-19 designated ward/ICUs were divided into two groups as those without CKD (Group 1) and with CKD (Group 2). Non COVID-19 cases with CKD from Nephrology OPD have been included in Group 3.

Inclusion and exclusion criteria are listed as below:

\begin{tabular}{|l|c|c|c|}
\hline \multicolumn{1}{|c|}{ INCLUSION CRITERIA } & \multicolumn{2}{|c|}{ GROUPS } \\
\cline { 2 - 4 } & GROUP 1 & GROUP 2 & GROUP 3 \\
\hline $\begin{array}{l}\text { 1. Patients who were symptomatic and } \\
\text { tested positive forSARS-CoV-2 by RT- } \\
\text { PCR test }\end{array}$ & + & + & \\
\hline 2. Sex. (Male/Female) & & & \\
\hline 3.Age $\geq 18$ years & M/F & M/F & M/F \\
\hline
\end{tabular}


medRxiv preprint doi: https://doi.org/10.1101/2021.07.16.21260406; this version posted July 22, 2021. The copyright holder for this preprint (which was not certified by peer review) is the author/funder, who has granted medRxiv a license to display the preprint in perpetuity. It is made available under a CC-BY-ND 4.0 International license .

\begin{tabular}{|l|c|c|c|}
\hline $\begin{array}{l}\text { 4.History of chronic kidney disease } \\
\text { (CKD) }\end{array}$ & - & + & + \\
& & & \\
\hline
\end{tabular}

Exclusion criteria - Pregnant and lactating females, patients on hemo-dialysis/ESRD as well as patients with previous history of CLD or preexisting cardiac disease (CHD)

All samples were collected adhering to bio-safety guidelines and received according to ICMR 2019 guidelines of COVID-19 management, in plain vacutainers with triple layer packaging. They were processed for liver function tests (LFT) - AST [ULN (upper limit of normal)- 41U/L], ALT [ULN-40U/L], ALP [ULN-135 U/L] and renal function tests (Serum Urea and Creatinine) in COVID-19 (Trauma center) Laboratory, Department of Biochemistry, Dr. RML Hospital New Delhi. The cases with elevated liver enzyme values were considered to have abnormal liver function. Those with ALT, AST values > 3xULN, and ALP>2.5xULN, were classified as those having liver injury. Serum AST \& ALT were estimated by ERBA Mannheim XL system Pack IFCC recommended without pyridoxal phosphate reagent; serum ALP was estimated by using ERBA Mannheim XL system Pack German society of clinical chemistry recommended ALP AMP method; serum Urea was estimated by urease GLDH method and serum creatinine was estimated by enzymatic method on the venous blood samples after separation of serum by proper centrifugation. The samples were processed on fully automated ERBA XL 640 Chemistry Analyzer (TRANSASIA Bio-medicals, India) after verification of two levels of internal quality controls. The present study was approved by the Institutional Ethics Committee [416(65/2020)/IEC/ABVIMS/RMLH/222].

Statistical analysis: The data were analyzed using SPSS statistical software (v 24; IBM Corporation, Armonk, NY, USA). The data was checked for normality using Shapiro-Wilk's test. Data is represented as mean and standard deviation for the serum levels of AST, ALT and ALP in all the three groups. The means of the different parameters in three groups were compared by one-way analysis of variance (ANOVA). These comparisons were followed by post-hoc comparisons between groups by means of the Tukey's test and a $P<0.05$ was considered statistically significant. The gender distribution was also compared among the three groups using Chi-square test. The linear relationship between the variables (test 
medRxiv preprint doi: https://doi.org/10.1101/2021.07.16.21260406; this version posted July 22, 2021. The copyright holder for this preprint (which was not certified by peer review) is the author/funder, who has granted medRxiv a license to display the preprint in perpetuity.

It is made available under a CC-BY-ND 4.0 International license .

parameters) was assessed using the Spearman Rank Correlation analysis method. At 95\% confidence interval, a p value of $\leq 0.05$ was considered significant.

\section{RESULT}

The three groups age and sex matched. There was no statistically significant difference $(\mathrm{P}>0.05)$ between the mean ages in the three groups. No significant difference $(\mathrm{P}>0.05)$ was observed between the percentages of females in the three groups as shown in Table no 1.

Table 1: Demographic characteristics of the three study Groups-1, 2, 3 (Group 1 COVID-19 without CKD, Group 2 COVID-19 with CKD, Group 3 Non-COVID-19 with CKD)

\begin{tabular}{|c|c|c|c|c|}
\hline $\begin{array}{c}\text { Demographic } \\
\text { parameters }\end{array}$ & Group 1 & Group 2 & Group 3 & p value \\
\hline $\begin{array}{c}\text { Age in years } \\
(\text { mean } \mathbf{S D})\end{array}$ & $49.29 \pm 18.52$ & $54.84 \pm 15.01$ & $53.61 \pm 14.49$ & 0.724 \\
\hline Range in years & $18-77$ & $21-79$ & $29-75$ & \\
\hline Female (\%) & 37.8 & 42.2 & 36.7 & 0.578 \\
\hline
\end{tabular}

Of the 400 patients with COVID-19 whose test reports were analyzed, $61.5(\%)$ had abnormal liver function and $11.5(\%)$ had liver injury during hospitalization.

Table 2: LFT outcomes amongst the 3 groups:

\begin{tabular}{|l|l|l|l|}
\hline \multirow{2}{*}{$\begin{array}{l}\text { Pest } \\
\text { Parameters (U/L) }\end{array}$} & $\begin{array}{l}\text { GROUP 1 } \\
(\mathbf{n = 2 0 0})\end{array}$ & $\begin{array}{l}\text { GROUP 2 } \\
(\mathbf{n = 2 0 0})\end{array}$ & $\begin{array}{l}\text { GROUP 3 } \\
(\mathbf{n = 2 0 0})\end{array}$ \\
\cline { 2 - 4 } & Mean \pm SD & Mean \pm SD & Mean \pm SD \\
\hline AST & $63.63 \pm 42.89$ & $90.59 \pm 62.51$ & $25.24 \pm 7.47$ \\
\hline ALT & $50.29 \pm 46.53$ & $72.09 \pm 67.24$ & $24.93 \pm 11.44$ \\
\hline ALP & $123.39 \pm 78.31$ & $185.38 \pm 92.70$ & $186.22 \pm 76.29$ \\
\hline
\end{tabular}

Table 3: Correlation between LFT outcomes amongst the 3 groups: 


\begin{tabular}{|l|c|l|l|l|l|l|}
\hline \multirow{2}{*}{$\begin{array}{l}\text { Pest } \\
\text { Parameters }\end{array}$} & \multicolumn{2}{|c|}{ GROUP 1 } & \multicolumn{2}{c|}{ GROUP 2 } & \multicolumn{2}{c|}{ GROUP 3 } \\
\hline \multirow{2}{*}{ AST } & \multicolumn{2}{|c|}{$p$ value } & \multicolumn{2}{c|}{$p$ value } & \multicolumn{2}{c|}{$p$ value } \\
& 2 & 0.002 & 1 & 0.002 & 1 & 0.001 \\
\cline { 2 - 8 } & 3 & 0.001 & 3 & 0.001 & 2 & 0.001 \\
\hline ALT & 2 & 0.002 & 1 & 0.002 & 1 & 0.001 \\
\cline { 2 - 8 } & 3 & 0.001 & 3 & 0.001 & 2 & 0.001 \\
\hline ALP & 2 & 0.001 & 1 & 0.001 & 1 & 0.001 \\
\cline { 2 - 8 } & 3 & 0.001 & 3 & 0.998 & 2 & 0.998 \\
\hline
\end{tabular}

Table no 2 and 3 showing statistical comparisons of the means of the three groups made by one way ANOVA, followed by post-hoc analysis. A value of $(\mathrm{P}<0.05)$ of the mean difference for the parameters in the 3 groups was considered to be significant.

As described in Table no 2 and 3 AST levels were significantly higher in all COVID-19 positive patients irrespective of their renal function status. AST levels were significantly higher in both Group 1 mean \pm 2 $\mathrm{SD}(63.63 \pm 42.89 \mathrm{U} / \mathrm{L})$ and Group $2(90.59 \pm 62.51 \mathrm{U} / \mathrm{L})$ as compared to Group $3(25.24 \pm 7.47 \mathrm{U} / \mathrm{L})(\mathrm{P}<$ 0.05). There was also a statistically significant elevation of serum AST levels in patients belonging to Group 2 as compared to patients in Group $1(P=0.002)$.

Figure 1: Simple Bar Chart showing mean of the Serum AST values in the 3 groups 
medRxiv preprint doi: https://doi.org/10.1101/2021.07.16.21260406; this version posted July 22, 2021. The copyright holder for this preprint (which was not certified by peer review) is the author/funder, who has granted medRxiv a license to display the preprint in perpetuity.

It is made available under a CC-BY-ND 4.0 International license .



Similarly, serum ALT levels were also significantly higher in both Group 1, mean \pm 2 SD $(50.25 \pm 46.53$ $\mathrm{U} / \mathrm{L})$ and Group $2(72.09 \pm 67.24 \mathrm{U} / \mathrm{L})$ as compared to Group $3(24.93 \pm 11.50 \mathrm{U} / \mathrm{L})(\mathrm{P}<0.05)$. There was a significant difference seen between groups 1 , group 2 , and group 3 ( $p=0.001,0.002,0.001)$ respectively.

Figure 2: Simple Bar Chart showing mean of the Serum ALT values in the 3 groups 
medRxiv preprint doi: https://doi.org/10.1101/2021.07.16.21260406; this version posted July 22, 2021. The copyright holder for this preprint (which was not certified by peer review) is the author/funder, who has granted medRxiv a license to display the preprint in perpetuity.

It is made available under a CC-BY-ND 4.0 International license .

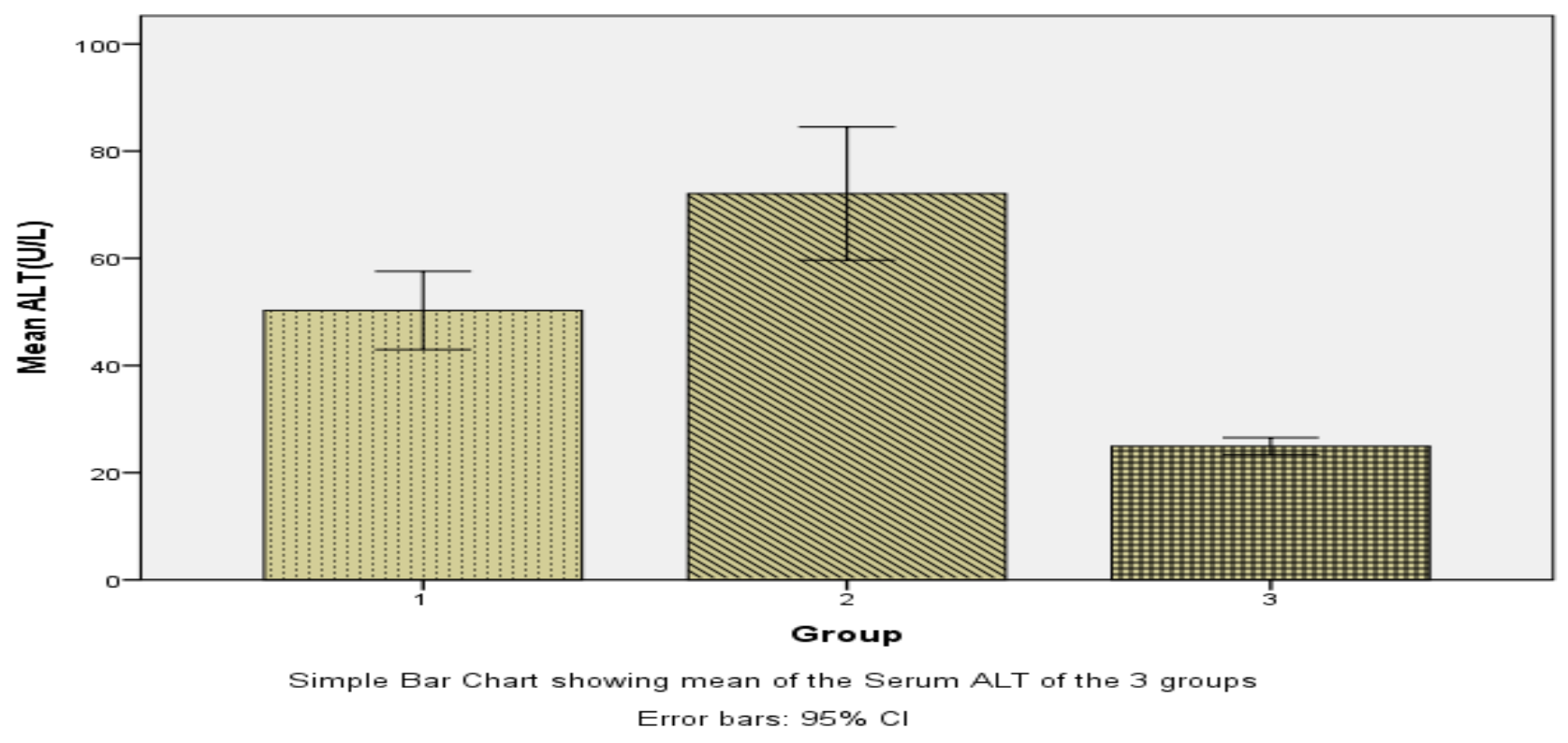

On the contrary serum ALP levels were significantly lower in Group 1, mean \pm 2 SD, $(123.39 \pm 78.31 \mathrm{U} / \mathrm{L})$ ( $\mathrm{p}<0.05)$ as compared to Group $2(185.38 \pm 92.70 \mathrm{U} / \mathrm{L})$ and Group $3(186.22 \pm 76.29 \mathrm{U} / \mathrm{L})$. The average serum ALP levels of Groups $2 \& 3$ were more or less comparable, and no significant difference was seen $(\mathrm{p}=0.998)$.

Figure 3: Simple Bar Chart showing mean of the Serum ALP values in the 3 groups




medRxiv preprint doi: https://doi.org/10.1101/2021.07.16.21260406; this version posted July 22, 2021. The copyright holder for this preprint (which was not certified by peer review) is the author/funder, who has granted medRxiv a license to display the preprint in perpetuity.

It is made available under a CC-BY-ND 4.0 International license.

Correlation studies between eGFR values and liver enzyme levels was performed in all the three groups as represented in table no 4. There was a negative correlation between eGFR and AST levels in Group 1 (Spearman's rho $=0.017$ and $\mathrm{p}<0.05$ ). A similar but stronger trend was observed in case of ALT $($ rho $=$ 0.001, $\mathrm{p}<0.01$ ). However no significant correlation existed between eGFR and ALP. In Group 2, no statistically significant correlation was seen between eGFR and AST or ALP values. However, a weak positive correlation was seen with ALT (rho $=0.006, \mathrm{p}<0.01$ ). In Group 3, eGFR showed strong positive correlations with AST and ALT levels (rho $=0.001, \mathrm{p}<0.01$; rho=0.001, $\mathrm{p}<0.01$ ) while reduction in kidney function correlated well with increase in serum ALP levels, (rho $=0.001, \mathrm{p}<0.01)$.

Table 4: Correlation between eGFR and LFT amongst the 3 group

\begin{tabular}{|c|c|c|c|c|c|c|}
\hline \multirow{3}{*}{$\begin{array}{l}\text { LFT } \\
\text { Parameters }\end{array}$} & \multicolumn{2}{|c|}{ GROUP 1} & \multicolumn{2}{|c|}{ GROUP 2} & \multicolumn{2}{|c|}{ GROUP 3} \\
\hline & eGFR & $p$ value & eGFR & $p$ value & eGFR & p value \\
\hline & $\begin{array}{c}\text { Correlation } \\
\text { Coefficient } \\
\text { (rho) }\end{array}$ & Sig. & $\begin{array}{c}\text { Correlation } \\
\text { Coefficient } \\
\text { (rho) }\end{array}$ & Sig. & $\begin{array}{c}\text { Correlation } \\
\text { Coefficient } \\
\text { (rho) }\end{array}$ & Sig. \\
\hline $\begin{array}{c}\text { AST } \\
\text { (SGOT) }\end{array}$ & -0.151 & 0.017 & 0.134 & 0.061 & 0.786 & 0.001 \\
\hline $\begin{array}{c}\text { ALT } \\
(\mathrm{SGPT})\end{array}$ & -0.200 & 0.001 & 0.194 & 0.006 & 0.807 & 0.001 \\
\hline$\overline{A L P}$ & 0.121 & 0.055 & 0.019 & 0.786 & -0.438 & 0.001 \\
\hline
\end{tabular}


medRxiv preprint doi: https://doi.org/10.1101/2021.07.16.21260406; this version posted July 22, 2021. The copyright holder for this preprint (which was not certified by peer review) is the author/funder, who has granted medRxiv a license to display the preprint in perpetuity. It is made available under a CC-BY-ND 4.0 International license .

\section{DISCUSSION}

CKD is classified by the National Kidney Foundation guidelines, into 5 stages. This is based on the calculation of estimated GFR (eGFR) ${ }^{8}$. The Modification of Diet in Renal Disease (MDRD) Study equation is the most widely used equation for estimating GFR in patients aged 18 yrs. and over. ${ }^{9}$

$$
\operatorname{eGFR}\left(\mathrm{mL} / \mathrm{min} / 1.73 \mathrm{~m}^{2}\right)=1.86 \times(\mathrm{PCr})^{*}-1.154 \times(\text { age })-0.203
$$

[Multiplied by 0.742 for women and by 1.21 for African Americans. PCr*-Plasma Creatinine.]

In Stage 1 eGFR is $\geq 90 \mathrm{~mL} / \mathrm{min} / 1.73 \mathrm{~m}^{2}$ with presence of kidney damage like persistent proteinuria, abnormal blood, and urine chemistry etc. Stages 2, 3 and 4 correspond to eGFR of $60-89 \mathrm{~mL} / \mathrm{min} / 1.73$ $\mathrm{m}^{2}, 30-59 \mathrm{~mL} / \mathrm{min} / 1.73 \mathrm{~m}^{2}$ and $15-29 \mathrm{~mL} / \mathrm{min} / 1.73 \mathrm{~m}^{2}$, respectively. The prime objective of treatment is to retard the progression of $\mathrm{CKD}$, perform cardiovascular disease risk estimation and manage the complications ${ }^{9}$ CKD stage 5 corresponds to eGFR $15 \mathrm{~mL} / \mathrm{min} / 1.73 \mathrm{~m}^{2}$ and is also known as end stage renal disease (ESRD).

In our study, CKD stage 3 and 4 patients were considered in Groups $2 \&$ 3. The association of comorbidities is a characteristic of chronic kidney disease. Derangements of hepatic function is one of the most important co-morbid conditions commonly seen with CKD and may be particularly confounding in cases with associated COVID-19. Numerous studies have shown that hepatic enzymes levels act as good prognostic markers in CKD including ESRD. ${ }^{10-11}$ Several studies have concluded, that, there is a decrease in the level of serum amino-transferases in patients with CKD compared to the normal population. Ray L. et al concluded that serum aminotransferase levels tend to remain lower in ESRD patients compared to the normal population, and levels further reduce with the worsening of CKD. ${ }^{10}$

The pathophysiological mechanism for the reduction in the serum aminotransferase levels in patients with CKD remains controversial. The possible mechanisms include reduction in pyridoxal-5-phosphate which is a coenzyme of aminotransferase, presence of ultraviolet absorbing materials, and high levels of uremic toxins ${ }^{10}$. Other possibilities included decreased synthesis and inhibition of release of AST and ALT from hepatocytes or accelerated clearance from serum. ${ }^{13-16}$ A low serum aminotransferase level could also be due to water retention and hemodilution in patients of CKD. ${ }^{10}$ However, this pattern is usually not maintained in CKD with COVID-19. In our study we included patients from this group.

Different meta-analytical and independent studies have shown, that, more than half of patients with COVID-19 (SARS-CoV-2) showed varying levels of liver involvement. Several case reports have also 
medRxiv preprint doi: https://doi.org/10.1101/2021.07.16.21260406; this version posted July 22, 2021. The copyright holder for this preprint (which was not certified by peer review) is the author/funder, who has granted medRxiv a license to display the preprint in perpetuity. It is made available under a CC-BY-ND 4.0 International license .

indicated that a significant number amongst them show evidence of liver damage too. ${ }^{17-19} \mathrm{About} 30 \%$ of all COVID-19, RT PCR positive admissions in our hospital, had abnormally high levels of serum creatinine at the time of presentation. This intensive derangement of renal function may have been due to the acute deterioration of renal function related to COVID-19 (SARS-CoV-2) disease or increased susceptibility to secondary infection in them. ${ }^{20}$ Other possible reasons for the high prevalence of kidney involvement, is that some of the patients with COVID-19 infection, had a previously documented history of CKD.

Liver damage in patients with coronavirus infection might be directly caused by the viral infection of liver cells. ${ }^{21}$ Two recent studies showed that angiotensin converting enzyme 2 (ACE2) was the key receptor for COVID-19 (SARS-CoV-2) cell entry. ${ }^{21-23}$ which was mainly localized in the heart, kidney and testes, and expressed at a low level in many other tissues, especially in the colon and lung. ${ }^{24}$ A study showed that COVID-19 (SARS-CoV-2) might directly bind to ACE2 positive cholangiocytes and cause liver damage, which may partially explain the contribution of SARS-CoV-2 infection to the liver test dysfunction in our patients. The virus may bind to angiotensin converting enzyme 2 (ACE2) cholangiocytes, leading to cholangiocytes dysfunction and inducing a systemic inflammatory response leading to liver injury. ${ }^{23,25}$ Moreover, the use of ACE-inhibitors and angiotensin receptor blocker (ARBs) drugs might also affect liver tests. ${ }^{26}$ Another possible reason behind this, is the use of hepatotoxic drugs like the antiviral remdesivir, oxidative stress, coexisting systemic inflammatory response, respiratory distress induced hypoxia and associated multi-organ dysfunction. . $^{17,27,28}$

In our study serum AST levels were significantly higher in all COVID-19 positive patients irrespective of their renal function status. Also, there was a statistically significant elevation in Group 2 as compared to Group $1(P<0.05)$. Similarly, serum ALT levels were also significantly, higher in both Group 1, and Group 2 as compared to Group 3 ( $\mathrm{P}<0.05)$. Also, there was a significant difference seen between group 1 and group $2(\mathrm{p}<0.05)$. Thus, the findings of serum AST and ALT levels are not in consonance with those seen in non-COVID-19 CKD patients and show an increase rather than a decrease. However, serum ALP levels were significantly lower in Group 1 as compared to Group 2 and 3, thereby indicating a higher strength of association of ALP values with CKD than non-CKD cases. The average serum ALP level of Group 2 and 3 were comparable. ALP levels in both the latter groups show a rising trend with a marginal increase in the mean of group $3(185.38 \pm 92.70 \mathrm{U} / \mathrm{L})$ in comparison to group $2(186.22 \pm 76.29 \mathrm{U} / \mathrm{L})$.

In Group 1 a negative correlation is seen between eGFR and AST $(\mathrm{p}<0.05)$. A similar but stronger trend was observed in case of ALT ( $\mathrm{p}<0.01)$. In Group 2, both AST and ALT showed a weak positive correlation with eGFR; it was statistically significant only with the latter (ALT) $(\mathrm{p}<0.01)$, signifying a reduction in ALT levels with deteriorating kidney function, in the COVID-19 positive CKD cases. A positive correlation existed between eGFR and ALP in groups 1 and 2, but this was not significant. In Group 3, eGFRs showed 
medRxiv preprint doi: https://doi.org/10.1101/2021.07.16.21260406; this version posted July 22, 2021. The copyright holder for this preprint (which was not certified by peer review) is the author/funder, who has granted medRxiv a license to display the preprint in perpetuity. It is made available under a CC-BY-ND 4.0 International license .

strong positive correlations with AST and ALT levels $(\mathrm{p}<0.01)$ and reduction in kidney function correlated well with increase in serum ALP levels, $(\mathrm{p}<0.01)$.

The association between ALP and renal damage may be, at least in part, explained by endothelial dysfunction, a strong and independent predictor of cardiovascular events in different clinical conditions, including essential hypertension ${ }^{29}$ which is one of the leading causes of CKD stage 4. Mechanisms linking ALP to endothelial dysfunction may include inhibition of tyrosine kinase activity into endothelial cells with consequent impairment of endothelial NO synthase function, promotion of high production of reactive oxygen species (ROS), and apoptosis due to increased degradation of pyrophosphate promoting atherosclerotic lesions in vascular wall. ${ }^{19,30-32}$ Thus, elevated ALP values in CKD patients may be used as an indicator of declining kidney function as corroborated by Angela Sciacqua et al. ${ }^{29}$ who in their study have shown a significant negative correlation between eGFR and ALP.

However, in stark contrast to the findings of Ray et al. ${ }^{10}$ there is a paradigm shift with respect to serum aminotransferase levels in COVID-19 afflicted CKD patients, which show elevations from baseline levels and lie beyond normal laboratory ranges, this is quite in contrary to that seen in the non-COVID-19 cases with CKD. Mean ALT though elevated, has shown a negative and positive correlation with e-GFR in group 1 and 2 respectively thereby signifying a proportionate fall in enzyme levels with progressive decline in kidney function in Group 2 patients of CKD, with SARS- Cov-2 infection.

\section{CONCLUSION}

Our study is the first of this kind on the Indian population, and most comprehensively describes that SARSCoV-2 positive CKD patients show more elevations in serum aminotransferase levels as compared to their SARS-CoV-2 positive non-CKD counterparts. Serum ALT values in all SARS-CoV-2 patients show significant correlation (positive or negative) with calculated eGFR values. Thus, ALT may be used as a marker to assess severity of disease and monitor therapeutic response during management of these patients. Also, elevated ALP values in CKD patients may be used as an indicator of declining kidney function.

However, more studies in this direction are needed.

Conflict of Interest: The authors declare no conflict of interest.

\section{References:}

1. Voice from China: nomenclature of the novel coronavirus and related diseases. Chin Med J (Engl) [Internet]. 2020 May 5 [cited 2021 Jul 4];133(9):1012-4. Available from: https://www.ncbi.nlm.nih.gov/pmc/articles/PMC7213625/ 
2. "Naming the coronavirus disease (COVID-2019) and the virus that causes it". World Health Organization. Archivedfrom the original on 28 February 2020.

3. India Situation Report [Internet]. [cited 2021 Jul 7]. Available from: https://www.who.int/india/emergencies/coronavirus-disease-(covid-19)/indiasituation-report

4. Yuki K, Fujiogi M, Koutsogiannaki S. COVID-19 pathophysiology: A review. ClinImmunol [Internet]. 2020 Jun [cited 2021 Jul 4];215:108427. Available from: https://www.ncbi.nlm.nih.gov/pmc/articles/PMC7169933/

5. Behzad S, Aghaghazvini L, Radmard AR, Gholamrezanezhad A. Extrapulmonary manifestations of COVID-19: Radiologic and clinical overview. Clin Imaging [Internet]. 2020 Oct [cited $2021 \mathrm{Jul}$ 4];66:35-41. Available from: https://www.ncbi.nlm.nih.gov/pmc/articles/PMC7233216/

6. Lee I-C, Huo T-I, Huang Y-H. Gastrointestinal and liver manifestations in patients with COVID19. J Chin Med Assoc [Internet]. 2020 Apr 21 [cited 2021 Jul 4];10.1097/JCMA.0000000000000319. Available from: https://www.ncbi.nlm.nih.gov/pmc/articles/PMC7176263/

7. Zheng Y-Y, Ma Y-T, Zhang J-Y, Xie X. COVID-19 and the cardiovascular system. Nat Rev Cardiol. 2020 May;17(5):259-60.

8. National Kidney Foundation, National Kidney Foundation, Kidney Disease Outcomes Quality Initiative. Clinical practice guidelines for chronic kidney disease: evaluation, classification and stratification. 2002.

9. Levey A et al. A more accurate method to estimate glomerular filtration rate from serum creatinine: a new prediction equation. Ann Int Med 2003 (July 15); 139: 137-47.

10. Ray L, Nanda SK, Chatterjee A, Sarangi R, Ganguly S. A comparative study of serum aminotransferases in chronic kidney disease with and without end-stage renal disease: Need for new reference ranges. International Journal of Applied and Basic Medical Research [Internet]. 2015 Jan 1 [cited 2021 Jul 4];5(1):31. Available from: https://www.ijabmr.org/article.asp?issn=2229516X; year $=2015$; volume $=5$; issue $=1$; spage $=31$; epage $=35$; aulast $=$ Ray;type $=0$

11. Oyelade T, Alqahtani J, Canciani G. Prognosis of COVID-19 in Patients with Liver and Kidney Diseases: An Early Systematic Review and Meta-Analysis. Trop Med Infect Dis [Internet]. 2020

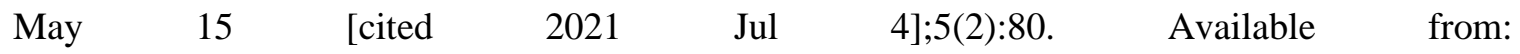
https://www.ncbi.nlm.nih.gov/pmc/articles/PMC7345004/

12. Goicoechea M, Sánchez Cámara LA, Macías N, Muñoz de Morales A, Rojas ÁG, Bascuñana A, et al. COVID-19: clinical course and outcomes of 36 hemodialysis patients in Spain. Kidney Int. 2020 Jul;98(1):27-34.

13. Hung KY, Lee KC, Yen CJ, Wu KD, Tsai TJ, Chen WY. Revised cutoff values of serum aminotransferase in detecting viral hepatitis among CAPD patients: experience from Taiwan, an endemic area for hepatitis B. Nephrol Dial Transplant. 1997 Jan;12(1):180-3.

14. Lopes EP, Sette LHBC, Sette JBC, Luna CF, Andrade AM, Moraes M, et al. Serum alanine aminotransferase levels, hematocrit rate and body weight correlations before and after hemodialysis session. Clinics [Internet]. 2009 [cited 2021 Jul 4];64:941-5. Available from: https://www.scielo.br/j/clin/a/dTYRJ8vDvyry5S9ZPwgPCys/?lang=en

15. Sette LHBC, de Almeida Lopes EP. Liver enzymes serum levels in patients with chronic kidney disease on hemodialysis: a comprehensive review. Clinics (Sao Paulo) [Internet]. 2014 Apr [cited 2021 Jul 4];69(4):271-8. Available from: https://www.ncbi.nlm.nih.gov/pmc/articles/PMC3971360/

16. Sabouri S, Afzal Aghaee M, Lotfi Z, Esmaily H, Alizadeh M, MosannenMozafari H. Evaluation of Liver Enzymes in End-Stage Renal Disease Patients on the Renal Transplant-Waiting List in 
medRxiv preprint doi: https://doi.org/10.1101/2021.07.16.21260406; this version posted July 22, 2021. The copyright holder for this preprint (which was not certified by peer review) is the author/funder, who has granted medRxiv a license to display the preprint in perpetuity. It is made available under a CC-BY-ND 4.0 International license .

North-West of Iran. Nephro-Urol Mon [Internet]. 2020 Nov 30 [cited 2021 Jul 4];12(4). Available from: https://sites.kowsarpub.com/num/articles/107859.html\#abstract

17. Bzeizi K, Abdulla M, Mohammed N, Alqamish J, Jamshidi N, Broering D. Effect of COVID-19 on liver abnormalities: a systematic review and meta-analysis. Sci Rep [Internet]. 2021 May 19 [cited 2021 Jul 4];11(1):10599. Available from: https://www.nature.com/articles/s41598-02189513-9

18. Yu D, Du Q, Yan S, Guo X-G, He Y, Zhu G, et al. Liver injury in COVID-19: clinical features and treatment management. Virology Journal [Internet]. 2021 Jun 9 [cited 2021 Jul 4];18(1):121. Available from: https://doi.org/10.1186/s12985-021-01593-1

19. Wu Z, Yang D. A meta-analysis of the impact of COVID-19 on liver dysfunction. European Journal of Medical Research [Internet]. 2020 Nov 4 [cited 2021 Jul 4];25(1):54. Available from: https://doi.org/10.1186/s40001-020-00454-x

20. Betjes MGH. Immune cell dysfunction and inflammation in end-stage renal disease. Nat Rev Nephrol. 2013 May;9(5):255-65.

21. Zhang C, Shi L, Wang F-S. Liver injury in COVID-19: management and challenges. Lancet GastroenterolHepatol. 2020 May;5(5):428-30.

22. Hoffmann M, Kleine-Weber H, Schroeder S, Krüger N, Herrler T, Erichsen S, et al. SARS-CoV-2 Cell Entry Depends on ACE2 and TMPRSS2 and Is Blocked by a Clinically Proven Protease Inhibitor. Cell [Internet]. 2020 Apr [cited 2021 Jul 2];181(2):271-280.e8. Available from: https://linkinghub.elsevier.com/retrieve/pii/S0092867420302294

23. Yan R, Zhang Y, Li Y, Xia L, Guo Y, Zhou Q. Structural basis for the recognition of SARS-CoV2 by full-length human ACE2. Science [Internet]. 2020 Mar 27 [cited 2021 Jul 4];367(6485):14448. Available from: https://science.sciencemag.org/content/367/6485/1444

24. Clarke NE, Turner AJ. Angiotensin-converting enzyme 2: the first decade. Int J Hypertens. 2012;2012:307315.

25. Chai X, Hu L, Zhang Y, Han W, Lu Z, Ke A, et al. Specific ACE2 Expression in Cholangiocytes May Cause Liver Damage After 2019-nCoV Infection. bioRxiv [Internet]. 2020 Feb 4 [cited 2021 Jul 4];2020.02.03.931766. Available from: https://www.biorxiv.org/content/10.1101/2020.02.03.931766v1

26. Qingxian Cai, Deliang Huang, Hong Yu, ., Jun Chen, Lei Liu, Lin Xu . COVID-19: Abnormal liver function tests Journal of Hepatology 2020 vol. 73 j 566-574

27. Fan Z, Chen L, Li J, Tian C, Zhang Y, Huang S, et al. Clinical Features of COVID-19-Related Liver Damage. medRxiv [Internet]. 2020 Feb 28 [cited 2021 Jul 4];2020.02.26.20026971. Available from: https://www.medrxiv.org/content/10.1101/2020.02.26.20026971v2

28. Yang L, Wang W, Wang X, Zhao J, Xiao L, Gui W, et al. Creg in Hepatocytes Ameliorates Liver Ischemia/Reperfusion Injury in a TAK1-Dependent Manner in Mice. Hepatology. 2019 Jan;69(1):294-313.

29. Sciacqua A, Tripepi G, Perticone M, Cassano V, Fiorentino TV, Pititto GN, et al. Alkaline phosphatase affects renal function in never-treated hypertensive patients: effect modification by age. Sci Rep [Internet]. 2020 Jun 17 [cited 2021 Jul 4];10:9847. Available from: https://www.ncbi.nlm.nih.gov/pmc/articles/PMC7299930/

30. Perticone F, Perticone M, Maio R, Sciacqua A, Andreucci M, Tripepi G, et al. Serum alkaline phosphatase negatively affects endothelium-dependent vasodilation in naïve hypertensive patients. Hypertension. 2015 Oct;66(4):874-80.

31. Schultz-Hector S, Balz K, Böhm M, Ikehara Y, Rieke L. Cellular localization of endothelial alkaline phosphatase reaction product and enzyme protein in the myocardium. $J$ 
medRxiv preprint doi: https://doi.org/10.1101/2021.07.16.21260406; this version posted July 22, 2021. The copyright holder for this preprint (which was not certified by peer review) is the author/funder, who has granted medRxiv a license to display the preprint in perpetuity.

It is made available under a CC-BY-ND 4.0 International license.

HistochemCytochem [Internet]. 1993 Dec 1 [cited 2021 Jul 4];41(12):1813-21. Available from: https://doi.org/10.1177/41.12.8245430

32. Romanelli F, Corbo A, Salehi M, Yadav MC, Salman S, Petrosian D, et al. Overexpression of tissue-nonspecific alkaline phosphatase (TNAP) in endothelial cells accelerates coronary artery disease in a mouse model of familial hypercholesterolemia. PLoS One. 2017;12(10):e0186426. 
$\underline{\text { An Evaluation of Liver Function Tests in SARS-CoV-2 infection in the backdrop of chronic kidney disease }}$

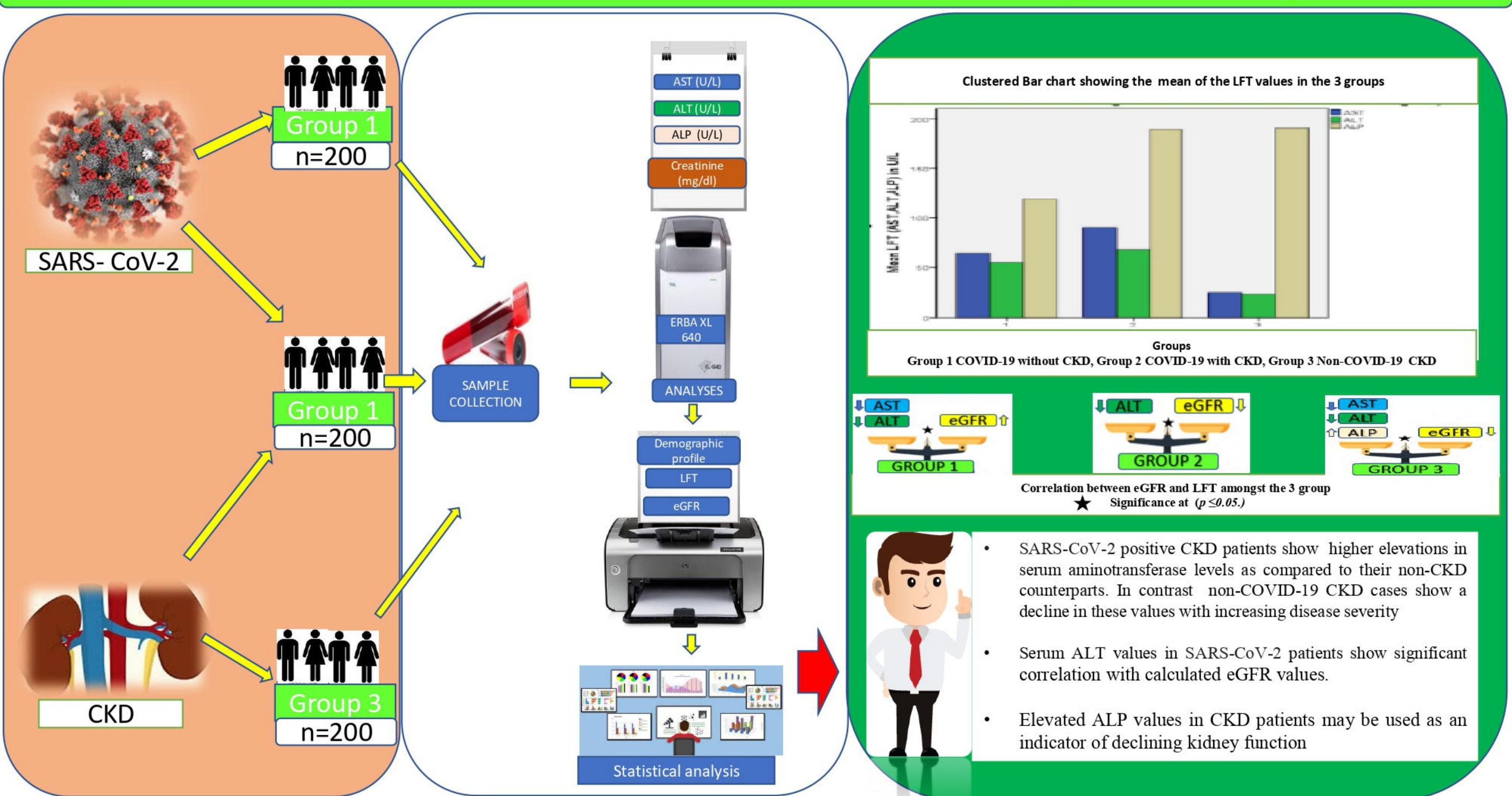


Dr.Smita Roy

Assistant Professor

Department of Biochemistry

ABVIMS \& Dr RML Hospital

New Delhi

Sub: The Research Project titled "An analysis of Myocardial Injury and Pulmonary Dysfunction in SARS-CoV-2: a Biochemical Perspective".

\section{Dear Sir/Madam}

The Institutional Ethics Committee, ABVIMS, Dr. RML Hospital, New Delhi discussed and reviewed your application seeking approval to conduct the above mentioned Research Project at its meeting held on $24^{\text {th }}$ July, 2020

\section{The following documents were reviewed and discussed}

1. Duly filled ethical proforma

2. Undertaking

3. Research protocol

4. CV

5. Letter dated 10.08 .2020

The following members of the Institutional Ethics Committee were present at the meeting held on $24^{\text {th }}$ July, 2020 at 11:00 AM in Room No.310, $3^{\text {td }}$ Floor, Administrative Block, ABVIMS building.

1. Dr. Arun Kumar Agarwal

Chairman

Ex-AddI DG MOHFW and Ex Dean MAMC

Legal Member

2. Dhirendra Kumar Jha, Advocate, Delhi High Court

3. Mr. H.R Meena, Deputy Secretary, Ministry of

Lay Person

Rural Development, NDCC - II Building, Jai Singh Poart

4. Prince Singhal, Social Activist \& Founder - CADO

5. Dr. (Prof.) Indu Chawla Consultant \& Head Deptt. Of Obst\&Gynae, ABVIMS \& Dr. RMLH

6. Dr Sanjeev Gupta, Department of Lab-Oncology

Dr Sanjeev
IRCH, AlIMS

7. Dr. Proteesh Rana, MO Dept of Pharmacology ABVIMS \& Dr. RMLH

8. Dr. Sudha Chandelia, Associate Professor Department of Pediatrics ABVIMS \& Dr. RML.H

\section{The Institutional Ethics Committee recommended the following:}

The Research Project titled "An analysis of Myocardial Injury anc P.jimonar Dysfunction in SARS-CoV-2: a Biochemical Perspective" is Approvect.

\section{Following points must be noted}

1. The decision was arrived at through consensus.

2. The IEC functions in accordance with the GCP-CDSCO/ICMR/Scheave * fanes amendments) guidelines/ICH-GCP.

3. The Institutional Ethics committee/Independent ethics comminese sucters is De informed about the progress of the study every 6 months, Any SAE acturning in the course of study, any changes in the protocol and Patient informancon lirriarme: Consent form and asks to be provided a copy of the finai report

4. The approval is for a period of 01 year

5. Kindly register with CTRI if applicable. 